\title{
Antagonism of chloride and nitrate inhibits nitrate reductase activity in chloride-stressed maize
}

\author{
Xudong Zhang ${ }^{1} \cdot$ Bastian L. Franzisky ${ }^{1} \cdot$ Lars Eigner $^{1} \cdot$ Christoph-Martin Geilfus $^{2} \cdot$ Christian Zörbb $^{1}$
}

Received: 27 July 2020 / Accepted: 21 November 2020 / Published online: 22 January 2021

(c) The Author(s) 2021

\begin{abstract}
Chloride $\left(\mathrm{Cl}^{-}\right)$is required for photosynthesis and regulates osmotic balance. However, excess $\mathrm{Cl}^{-}$application negatively interacts with nitrate $\left(\mathrm{NO}_{3}^{-}\right)$uptake, although its effect on $\mathrm{NO}_{3}^{-}$metabolism remains unclear. The aim was to test whether $\mathrm{Cl}^{-}$ stress disturbs nitrate reductase activity (NRA). A maize variety (Zea mays L. cv. LG 30215) was hydroponically cultured in a greenhouse under the following conditions: control $\left(2 \mathrm{mM} \mathrm{CaCl}_{2}\right)$, moderate $\mathrm{Cl}^{-}\left(10 \mathrm{mM} \mathrm{CaCl}_{2}\right)$, high $\mathrm{Cl}^{-}\left(60 \mathrm{mM} \mathrm{CaCl}_{2}\right)$. To substantiate the effect of $\mathrm{Cl}^{-}$stress further, an osmotic stress with lower intensity was induced by $60 \mathrm{~g}$ polyethylene glycol (PEG) $6000 \mathrm{~L}^{-1}+2 \mathrm{mM} \mathrm{CaCl}_{2}$ ), which was $57 \%$ of the osmotic pressure being produced by $60 \mathrm{mM} \mathrm{CaCl}_{2}$. Results show that high $\mathrm{Cl}^{-}$and PEG-induced osmotic stress significantly reduced shoot biomass, stomatal conductance and transpiration rate, but NRA was only decreased by high $\mathrm{Cl}^{-}$stress. The interference of NRA in chloride-stressed maize is supposed to be primarily caused by the antagonistic uptake of $\mathrm{Cl}^{-}$and $\mathrm{NO}_{3}^{-}$.
\end{abstract}

Keywords Chloride stress $\cdot$ Nitrate $\cdot$ Osmotic stress $\cdot$ Photosynthesis

\section{Introduction}

Salt stress caused by, for example, $\mathrm{NaCl}$ is a serious abiotic threat that imposes negative impacts on crop yield and the quality of plant products (Abdelaal et al. 2020; Naeem et al. 2020; Zörb et al. 2019). The unfavorable effects on plant growth are attributed to either osmotic stress or ion toxicity (Munns and Tester 2008). Chloride $\left(\mathrm{Cl}^{-}\right)$is the anion of $\mathrm{NaCl}$ and has multiple functions in plants (Geilfus 2018a; Wege et al. 2017). Being a micronutrient ( $\mu \mathrm{M}$ range), $\mathrm{Cl}^{-}$acts as a dominant functional element involved

Communicated by Jiayin Pang

Supplementary Information The online version contains supplementary material available at https://doi.org/10.1007/s1072 5-020-00685-2.

Christoph-Martin Geilfus geilfusc@hu-berlin.de

1 Institute of Crop Science, Quality of Plant Products, University of Hohenheim, Stuttgart, Germany

2 Division of Controlled Environment Horticulture, Faculty of Life Sciences, Albrecht Daniel Thaer Institute of Agricultural and Horticultural Sciences, Humboldt University of Berlin, Berlin, Germany in the oxygen-evolving complex of PSII of photosynthesis (Kawakami et al. 2009) and the regulation of enzymatic activity such as asparagine synthase (Rognes 1980) and V-ATPase in the tonoplast (Geilfus 2018b). When the $\mathrm{Cl}^{-}$concentration lies on a macronutrient level (low millimolar range), it can be beneficial for enhancing water-use efficiency and net photosynthesis rate $\left(\mathrm{A}_{\mathrm{N}}\right)$ (Rosales et al. 2020) and, as a consequence, for promoting plant growth and biomass production in citrus (Brumos et al. 2010) and tobacco plants (Franco-Navarro et al. 2019). The enhanced plant growth gives indication that $\mathrm{Cl}^{-}$might also increase nitrogen use efficiency (NUE) (Rosales et al. 2020). However, if $\mathrm{Cl}^{-}$application exceeds favorable doses, plants may suffer from disturbed ion homeostasis, photosynthetic disorders, reduced biomass, or even cell death (Geilfus 2018b; Wege et al. 2017).

Nitrate reductase (NR) is a substrate-induced enzyme that catalyzes the conversion of $\mathrm{NO}_{3}^{-}$to $\mathrm{NO}_{2}^{-}$and the production of nitric oxide (NO) (Chamizo-Ampudia et al. 2017; Crawford and Glass 1998; He et al. 2017). NR plays a pivotal role in massive biological processes such as photosynthesis, molecular biology in chloroplast, starch synthesis and metabolism, and nutrient availability and metabolism by regulating not only the availability of nitrite for nitrogen assimilation but also the homeostasis of the signaling 
molecule NO (Chamizo-Ampudia et al. 2017). As a substrate, the $\mathrm{NO}_{3}^{-}$concentration has been well documented as positively correlating with nitrate reductase activity (NRA) (Mengel et al. 1983; Hütsch et al. 2016); however, this correlation can differ depending on the analyzed tissue (Mengel et al. 1983). For instance, the correlation of $\mathrm{NO}_{3}^{-}$and NRA exhibits a saturation curve and a sigmoidal curve in maize leaves and roots, respectively (Mengel et al. 1983). Hence, NRA is inevitably regulated by the availability of the resource $\mathrm{NO}_{3}^{-}$. Stressful conditions have also been reported to decrease NRA in a dose-dependent manner, as shown with regard to water shortage (Larsson et al. 1989; Munjal et al. 1997) and $\mathrm{NaCl}$ stress (Botella et al. 1993; Khan et al. 1995) in various plant species. Reduced NRA is assumed to result from stress-related disturbances of NR expression ( $\mathrm{Lu}$ et al. 1992) and the conversion of the enzyme to an inactivated form (Munjal et al. 1997).

The monovalent macronutrient anion $\mathrm{NO}_{3}^{-}$possesses similar physical properties to $\mathrm{Cl}^{-}$(Wege et al. 2017). This similarity of physical properties leads to an antagonistic relationship in the uptake between these two anions. Under saline conditions, excess $\mathrm{Cl}^{-}$may reduce the availability of $\mathrm{NO}_{3}^{-}$as a substrate that supports the activity of NR. Moreover, the transport of $\mathrm{NO}_{3}^{-}$between the vacuole and cytoplasm is regulated by chloride channels such as AtCLCa (Zhang et al. 2017). The biosynthesis and activity of NR are also thought to be influenced by $\mathrm{Cl}^{-}$, but no experiments have been conducted to substantiate this speculation (Flores et al. 2000). Nevertheless, a direct causation between $\mathrm{Cl}^{-}$and the inhibition of NRA remains elusive in many crops such as maize. This might be because the sodium component of $\mathrm{NaCl}$ salinity has received more attention over the last few decades.

Maize, as a moderately salt $(\mathrm{NaCl})$-sensitive crop (Farooq et al. 2015), has recently been established to tolerate $\mathrm{Cl}^{-}$stress moderately in our previous work (Zhang et al. 2019). From this previous work, a mildly tolerant genotype was selected to answer the following questions: (i) does $\mathrm{Cl}^{-}$stress or osmotic stress influence maize growth and photosynthesis; (ii) does $\mathrm{Cl}^{-}$stress or osmotic stress influence on NRA in leaf tissues?

\section{Material and methods}

\section{Plant material and cultivation}

The maize variety (Zea mays L. cv. LG30215 supplied by LG c/o Limagrain $\mathrm{GmbH}$ ), mildly tolerant to $\mathrm{Cl}^{-}$stress (Zhang et al. 2019), was hydroponically cultured in 5-1 pots (two plants per pot) with four biological replicates for each of the treatments, respectively, in the greenhouse, which means eight plants in total under each condition (Fig. 1a).
Grains were germinated for 13 days in sand and transferred to hydroponic solutions at the two-leaf stage. The initial nutrient solution was one third of full strength and then was stepwise increased to two thirds and final full strength every second day. The full nutrient recipe (Richter et al. 2015; Zörb et al. 2015) contains the macronutrients $\mathrm{Ca}\left(\mathrm{NO}_{3}\right)_{2}$ $0.66 \mathrm{mM}, \mathrm{NH}_{4} \mathrm{NO}_{3} 1.33 \mathrm{mM}, \mathrm{KH}_{2} \mathrm{PO}_{4} 0.2 \mathrm{mM}, \mathrm{K}_{2} \mathrm{SO}_{4}$ $1.0 \mathrm{mM}, \mathrm{MgSO}_{4} 0.5 \mathrm{mM}, \mathrm{CaCl}_{2} 2 \mathrm{mM}$, and Fe-EDTA $0.2 \mathrm{mM}$ and the micronutrients $\mathrm{H}_{3} \mathrm{BO}_{3} 5.0 \mu \mathrm{M}, \mathrm{MnSO}_{4} 2$ $\mu \mathrm{M}, \mathrm{ZnSO}_{4} 0.5 \mu \mathrm{M}, \mathrm{CuSO}_{4} 0.3 \mu \mathrm{M}$, and $\left(\mathrm{NH}_{4}\right)_{2} \mathrm{Mo}_{7} \mathrm{O}_{24} 0.01$ $\mu \mathrm{M}$. Hydroponic solutions were changed twice a week. The initial $\mathrm{pH}$ value was approximately 6.1 , which could be kept constant without any precipitation for 4 days.

Maize seedlings were treated under the following conditions: control $\left(2 \mathrm{mM} \mathrm{CaCl}_{2}\right)$, moderate $\mathrm{Cl}^{-}(10 \mathrm{mM}$ $\left.\mathrm{CaCl}_{2}\right)$, high $\mathrm{Cl}^{-}\left(60 \mathrm{mM} \mathrm{CaCl}_{2}\right)$, and osmotic stress $(60 \mathrm{~g}$ $\mathrm{L}^{-1}$ PEG 6000 (Carl Roth GmbH + Co. KG, Karlsruhe, Germany) $+2 \mathrm{mM} \mathrm{CaCl}_{2}$ ). The reason to define $10 \mathrm{mM} \mathrm{CaCl}_{2}$ as moderate stress and $60 \mathrm{mM} \mathrm{CaCl}_{2}$ as high stress is that plant heights by both stresses were always lower than the control and the height of plants treated by $10 \mathrm{mM} \mathrm{CaCl}_{2}$ were constantly higher than those of $60 \mathrm{mM} \mathrm{CaCl}_{2}$ (Fig. S1). In order to substantiate the effects of $\mathrm{Cl}^{-}, 2 \mathrm{mM} \mathrm{CaCl} 2$ was added to PEG-induced osmotic stress, as in the control. PEG-induced osmotic pressure $\left(130.1 \mathrm{mOsm} \mathrm{kg}^{-1}\right)$ was only $57 \%$ of that produced by $60 \mathrm{mM} \mathrm{CaCl}_{2}\left(228.9 \mathrm{mOsm} \mathrm{kg}^{-1}\right)$. The effect of $\mathrm{Ca}^{2+}$ on maize growth can be excluded, because the $\mathrm{Ca}^{2+}$ concentration in young leaves was $10 \mathrm{mg} \mathrm{g}^{-1} \mathrm{DM}$ under $60 \mathrm{mM} \mathrm{CaCl}_{2}$, which is located in the reported optimal range (2.1 to $16 \mathrm{mg} \mathrm{g}^{-1} \mathrm{DM}$ ) for maize leaves (Gaj et al. 2018; Johnston and Dowbenko 2004). Thus, the detrimental effects of increased $\mathrm{Ca}^{2+}$ concentrations were considered to be marginal. The treatments were firstly applied to the plants in nutrient solutions, with half strength at the 7th day after transfer and were afterwards supplemented to reach full strength at the 9th day. The youngest fully developed leaf blade was selected at the first day of treatment. At the 28th day after transfer of the plants into the hydroponic solution, the whole plant was harvested and separated into four fractions (Fig. 1b): young part, fully developed leaf blade, old part, and root. Among them, the young part and old part were a mixture of corresponding leaf blades and leaf sheaths.

\section{Fresh weight and dry weight}

The fresh weight of each plant fraction was immediately obtained at harvest. The dry weight was measured after the leaves had been dried at $60{ }^{\circ} \mathrm{C}$ for 4 days in a ventilated oven. 


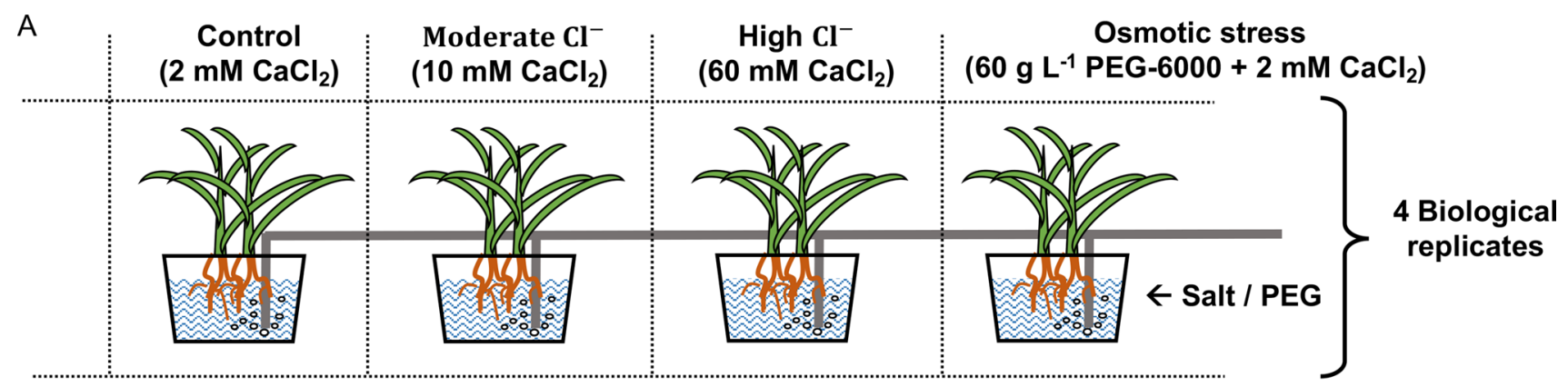

B

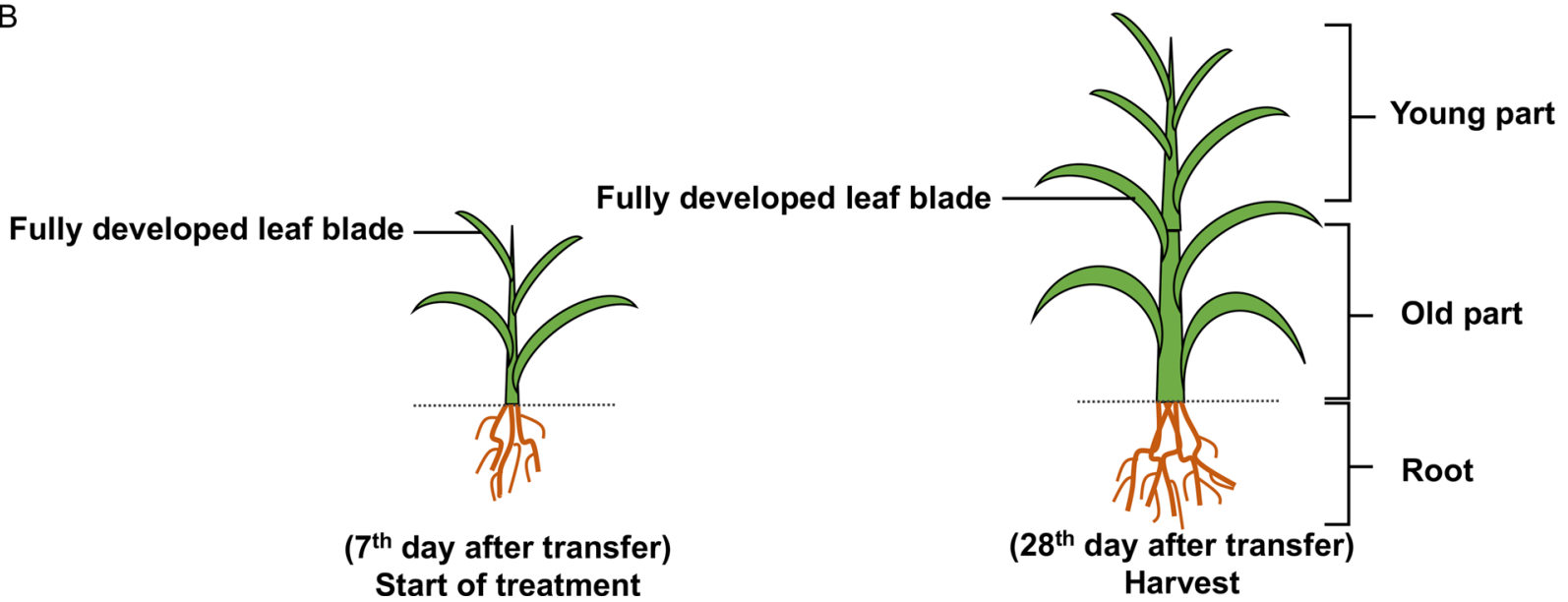

Fig. 1 Experimental design. a Experimental set-up of maize plants cultured in hydroponic solution, b diagrams of treatment application and harvest

\section{Chloride concentration}

Dry materials of each fraction were uniformly ground into fine powder by a mill (Retsch ZM1) equipped with a $0.5 \mathrm{~mm}$ sieve mesh. Plant tissue powder (200 mg) was dissolved in

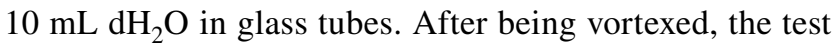
tubes were covered with glass beads to prevent the escape of water, heated at $80^{\circ} \mathrm{C}$ for $15 \mathrm{~min}$, and then quickly cooled for $7 \mathrm{~min}$ in the ice bath. The cooled extracts were filtered through pleated filters in $15 \mathrm{~mL}$ plastic centrifuge tubes. The $\mathrm{Cl}^{-}$concentration was determined by using a chloride meter (6610, Eppendorf AG, Hamburg, Germany) (Zhang et al. 2019). The extract solution $(100 \mu \mathrm{L})$ was pipetted into the titration solution (a mixture of $1 \mathrm{~mL}$ gelatin plus indicator solution, Biorapid GmbH, Freiburg, Germany) and $15 \mathrm{~mL}$ acid buffer $\left(6.4 \mathrm{~mL} \mathrm{~L}^{-1} 65 \%\right.$ nitric acid and $57.6 \mathrm{~mL} \mathrm{~L}^{-1}$ $100 \%$ acetic acid). Each sample was measured in three technical replicates.

\section{Nitrate reductase activity}

The activity of nitrate reductase (EC 1.7.1.1) was determined according to the method of Hageman and Hucklesby (Hageman and Hucklesby 1971) with slight modification. Frozen leaf material $\left(-80^{\circ} \mathrm{C}\right)$ was ground in liquid nitrogen, and $0.2 \mathrm{~g}$ of this leaf powder was weighed into $2 \mathrm{~mL}$ reaction vessels. After the addition of $1 \mathrm{~mL}$ digestion buffer $(100 \mathrm{mM}$ TRIS / HCl pH 8.0, $1 \mathrm{mM}$ EDTA, $10 \mathrm{mM}$ cysteine) with thorough vortexing, centrifugation was carried out at $4{ }^{\circ} \mathrm{C}$ for $10 \mathrm{~min}$ at $20,000 \times \mathrm{g}$. The supernatant was pipetted into a new reaction vessel and placed on ice. For each sample, two reaction tubes were prepared according to the following scheme: $400 \mu \mathrm{L}$ protein extract and $600 \mu \mathrm{L}$ reaction buffer (100 mM KNO 3 ; 1 mM NADH ${ }^{+} \mathrm{H}^{+} ; 1.08 \mathrm{mM} \mathrm{K}_{2} \mathrm{HPO}_{4}$; $1.47 \mathrm{mM} \mathrm{Na}_{2} \mathrm{HPO}_{4}$ ) were mixed (batch reaction). To one of the tubes (reference tube), $200 \mu \mathrm{L}$ batch stopper (zinc acetate dehydrate; $1 \mathrm{M} \mathrm{C}_{4} \mathrm{H}_{6} \mathrm{O}_{4} \mathrm{Zn} \bullet 2 \mathrm{H}_{2} \mathrm{O}$ ) was immediately added in order to estimate the initial concentration of $\mathrm{NO}_{2}^{-}$in leaf samples. This reference tube was subsequently incubated on ice for $30 \mathrm{~min}$. Meanwhile, the second tube with exclusive reaction buffer was also incubated for $30 \mathrm{~min}$ at $30^{\circ} \mathrm{C}$ before the batch stopper (zinc acetate, $200 \mu \mathrm{L}$ ) was added to stop the reaction. The reaction mixtures were then centrifuged at $20^{\circ} \mathrm{C}$ for $2 \mathrm{~min}$ at $20,000 \times \mathrm{g}$. Aliquots of $500 \mu \mathrm{L}$ supernatant from these two tubes were each subsequently pipetted into empty tubes, followed by the addition of $500 \mu \mathrm{L}$ sulfanilamide $\left(25 \% \mathrm{HCl} ; 10 \mathrm{mg} \mathrm{L}^{-1}\right.$ and $500 \mu \mathrm{L}$ naphthyl reagent (N-(1-naphthyl) ethylene diamine dihydrochloride; $0.2 \mathrm{mg}$ $\mathrm{L}^{-1}$ ) and allowed to stand for $15 \mathrm{~min}$ at room temperature for color development. For the blank and the calibration 
curve, a similar mixture was prepared in each case with 500 $\mu \mathrm{L} \mathrm{ddH_{2 }} \mathrm{O}$ or nitrite standards $(0.05 \mathrm{mM}, 0.1 \mathrm{mM}, 0.5 \mathrm{mM}$, $1 \mathrm{mM}, 5 \mathrm{mM}$, and $10 \mathrm{mM} \mathrm{KNO}_{2}$ ) replacing the supernatant. Finally, the absorbance at $540 \mathrm{~nm}$ was measured against the blank value with the multimode reader TriStar S LB 942 (Berthold Technologies, Bad Wildbad, Germany). The NRA is described as the weight of the formed reaction product $\left(\mathrm{NO}_{2}^{-}\right)$per tissue fresh mass and time $\left(\mu \mathrm{mol} \mathrm{NO} \mathrm{NO}_{2}^{-} \mathrm{g}^{-1} \mathrm{FM}\right.$ $\left.\mathrm{h}^{-1}\right)$. Three technical replicates were performed.

\section{Nitrate concentration}

$\mathrm{NO}_{3}^{-}$concentration was determined by a UV/Vis spectrophotometer (SPECORD®50 PLUS, Analytik Jena AG, Germany) via the nitration of salicylic acid (Xu et al. 2016) with a downscaling modification. In brief, liquid-ground maize leaf tissue $(100 \mathrm{mg})$ was dissolved in $1 \mathrm{~mL} \mathrm{dd} \mathrm{H}_{2} \mathrm{O}$ and heated at $90{ }^{\circ} \mathrm{C}$ for $30 \mathrm{~min}$. After being cooled to room temperature, samples were centrifuged at $14,000 \times g$ for $10 \mathrm{~min}$. The extracted supernatant $(20 \mu \mathrm{L})$ was transferred to new tubes in parallel with the same amount of standard solution and the blank reference. Salicylic acid-sulfuric acid $(80 \mu \mathrm{L})$ was added to the supernatant, completely mixed, and then incubated at room temperature for $20 \mathrm{~min}$. Subsequently, $\mathrm{NaOH}\left(1.9 \mathrm{~mL} ; 80 \mathrm{mg} \mathrm{L}^{-1}\right)$ was added to the tubes in order to generate a high alkaline environment in which samples were able fully to develop the color. These reaction tubes had to be cooled at room temperature for $30 \mathrm{~min}$, since the concentrated $\mathrm{NaOH}$ addition induced the release of heat. The absorbance of all samples was measured at the wavelength of $410 \mathrm{~nm}$ with the control as reference. Each sample was technically repeated three times.

\section{Estimated chlorophyll concentration}

The chlorophyll content of the fully developed leaf blade was estimated by SPAD meter (Model No. 502, Konica Minolta) (Ebert et al. 2002). For the sake of accuracy, leafy cubes from various positions on the fully developed leaf blade were randomly chosen on both sides of the central vein. The final value was averaged over three measurements.

\section{Stomatal conductance, transpiration rate, and net photosynthetic assimilation}

The fully developed leaf blade (Fig. 1b) was used for monitoring stomatal conductance $\left(\mathrm{g}_{\mathrm{s}}\right)$, transpiration rate $(\mathrm{E})$ and net photosynthetic rate $\left(\mathrm{A}_{\mathrm{N}}\right)$ with a LCi Portable Photosynthesis System installed with a broad chamber (ADC BioScientific Ltd) (Zhang et al. 2019). Illumination of the chamber mimicked natural sunlight ranging from 150 to $1200 \mu \mathrm{mol} \mathrm{m}^{-2} \mathrm{~s}^{-1}$ per leaf area. In the tested leaf blade,
$\mathrm{CO}_{2}$ diffusion into leaf chamber was $400 \mathrm{ppm}$, and $\mathrm{H}_{2} \mathrm{O}$ flux was $0.17 \mu \mathrm{mol} \mathrm{m} \mathrm{m}^{-2} \mathrm{~s}^{-1}$.

\section{Statistical analysis}

Data of all four biological replicates are used to make whisker-box plots. The significant difference between the control and other treatments was evaluated at the probability of 0.05 and 0.01 levels by two factor ANOVA and the LSD test with R studio 1.1.456 (R studio lnc, Boston, USA) with library (agricolae) (De Mendiburu 2017). Principal component analysis (PCA) was analyzed and plotted by R studio 1.1.456 (R studio lnc, Boston, USA) with function "prcomp" (Venables and Ripley 2002) and library (ggbiplot) (Vu 2016) on a basis of 16 parameters with biological replicates measured as above. The $\mathrm{Cl}^{-}$concentration, osmolality, NRA, and $\mathrm{NO}_{3}^{-}$concentration were measured within three technical replicates, respectively.

\section{Results}

\section{Plant biomass and plant height}

All plant organs showed significantly reduced fresh mass under high $\mathrm{Cl}^{-}\left(60 \mathrm{mM} \mathrm{CaCl}_{2}\right)$ or osmotic stress when compared with the control (Fig. 2a). No significant difference in fresh weight could be observed between moderate $\mathrm{Cl}^{-}$treatment and the control, except for the total shoot (Fig. 2a). In contrast, negative effects of high $\mathrm{Cl}^{-}$and osmotic treatment on dry weight were present in young tissue, old tissue, and shoots but not in roots (Fig. 2b). With the time of exposure to treatments increased, plant heights by $10 \mathrm{mM}$ $\mathrm{CaCl}_{2}, 60 \mathrm{mM} \mathrm{CaCl}_{2}$, and PEG-induced osmotic stress were constantly lower than the control. Among these treatments, $10 \mathrm{mM} \mathrm{CaCl}_{2}$ led to the highest plant height while osmotic stressed-plant was the lowest (Fig. S1).

\section{Chloride concentration of all fractions, nitrate reductase activity and nitrate concentration in the fully developed leaf blade}

$\mathrm{Cl}^{-}$concentrations of all plant tissues significantly rose with increasing $\mathrm{Cl}^{-}$application, except for young tissue under moderate $\mathrm{Cl}^{-}$treatment (Fig. 3a). Maximum of $\mathrm{Cl}^{-}$concentrations, as expected, appeared under high $\mathrm{Cl}^{-}$treatment. The $\mathrm{Cl}^{-}$concentration of all fractions under osmotic treatment was similar to that of the control, except for the fully developed leaf blade, which was slightly higher (Fig. 3a). This increase is attributable to 


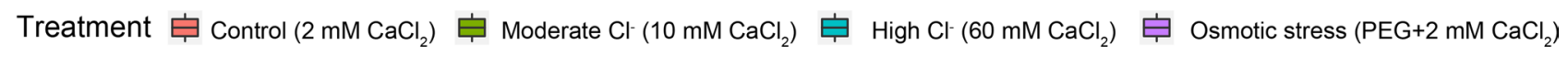

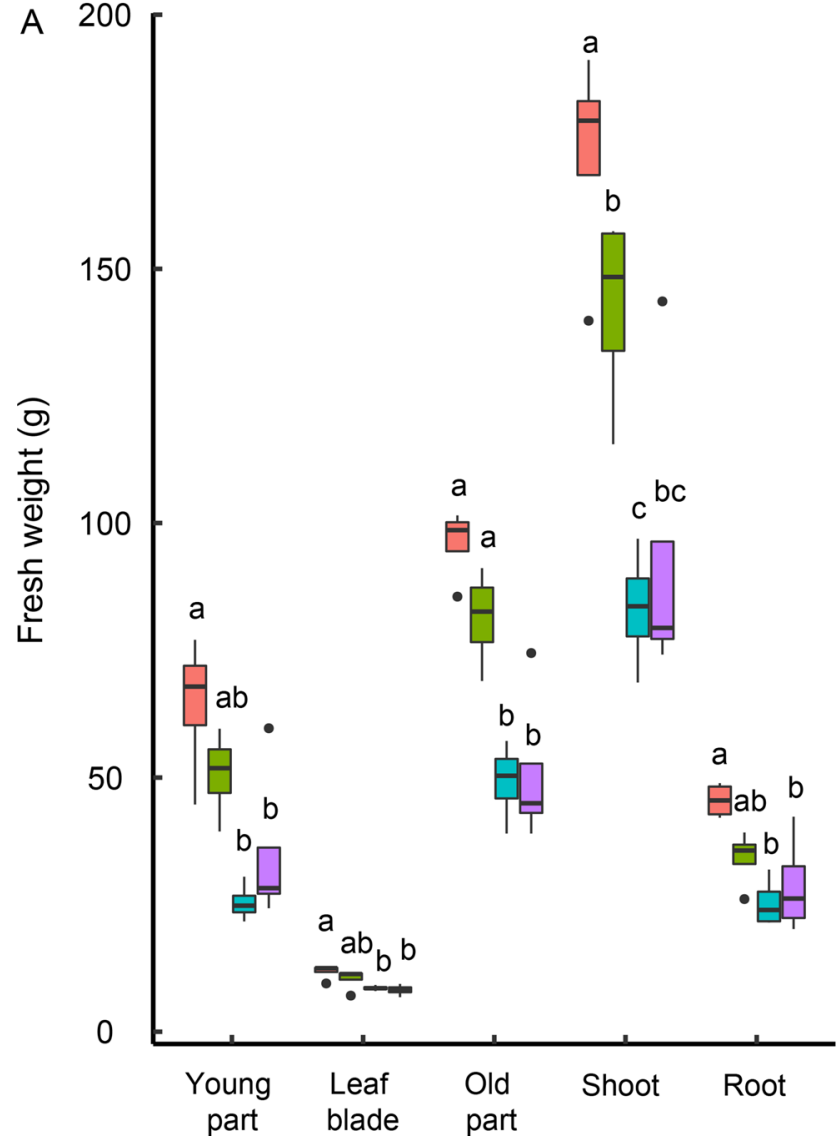

Fig. 2 Fresh and dry biomass of various fractions in maize. a fresh weight per pot, b dry weight per pot. Small letters represent significant differences $(\mathrm{P}<0.05$, LSD test) in one tissue group under the dif-

the fact that the treatment termed "osmotic treatment" also included $2 \mathrm{mM} \mathrm{CaCl}_{2}$. Under moderate to high $\mathrm{Cl}^{-}$application $(10 \mathrm{mM}$ to $60 \mathrm{mM} \mathrm{CaCl}$ ), more chloride accumulated in old tissues and roots than in younger tissues (Fig. 3a).

NR exhibited the greatest activity under control conditions $\left(0.37 \mu \mathrm{mol} \mathrm{NO} \mathrm{N}_{2}^{-} \mathrm{g}^{-1} \mathrm{FM} \mathrm{h}^{-1}\right)$ and moderate $\mathrm{Cl}^{-}$treatment $\left(0.43 \mu \mathrm{mol} \mathrm{NO}_{2}^{-} \mathrm{g}^{-1} \mathrm{FM} \mathrm{h}^{-1}\right)$, but the lowest activity appeared under high $\mathrm{Cl}^{-}$treatment $\left(0.17 \mu \mathrm{mol} \mathrm{NO}_{2}^{-} \mathrm{g}^{-1} \mathrm{FM}\right.$ $\mathrm{h}^{-1}$ ) (Fig. 3b). No difference was detected between PEGinduced osmotic treatment and control (Fig. 3b).

In accordance with $\mathrm{NR}, \mathrm{NO}_{3}^{-}$concentration showed the similar pattern. It is clear to see that $\mathrm{NO}_{3}^{-}$concentration $\left(0.0075 \mathrm{mmol} \mathrm{g}^{-1} \mathrm{FM}\right)$ was the lowest under high $\mathrm{Cl}^{-}$treatment and the maximum $\left(0.0265 \mathrm{mmol} \mathrm{g}^{-1} \mathrm{FM}\right)$ was observed in moderate $\mathrm{Cl}^{-}$treatment (Fig. 3c). In comparison with control, osmotic treatment (plus $2 \mathrm{mM}$ $\mathrm{CaCl}_{2}$ ) was associated with the same concentration of $\mathrm{NO}_{3}^{-}$ (Fig. 3c).

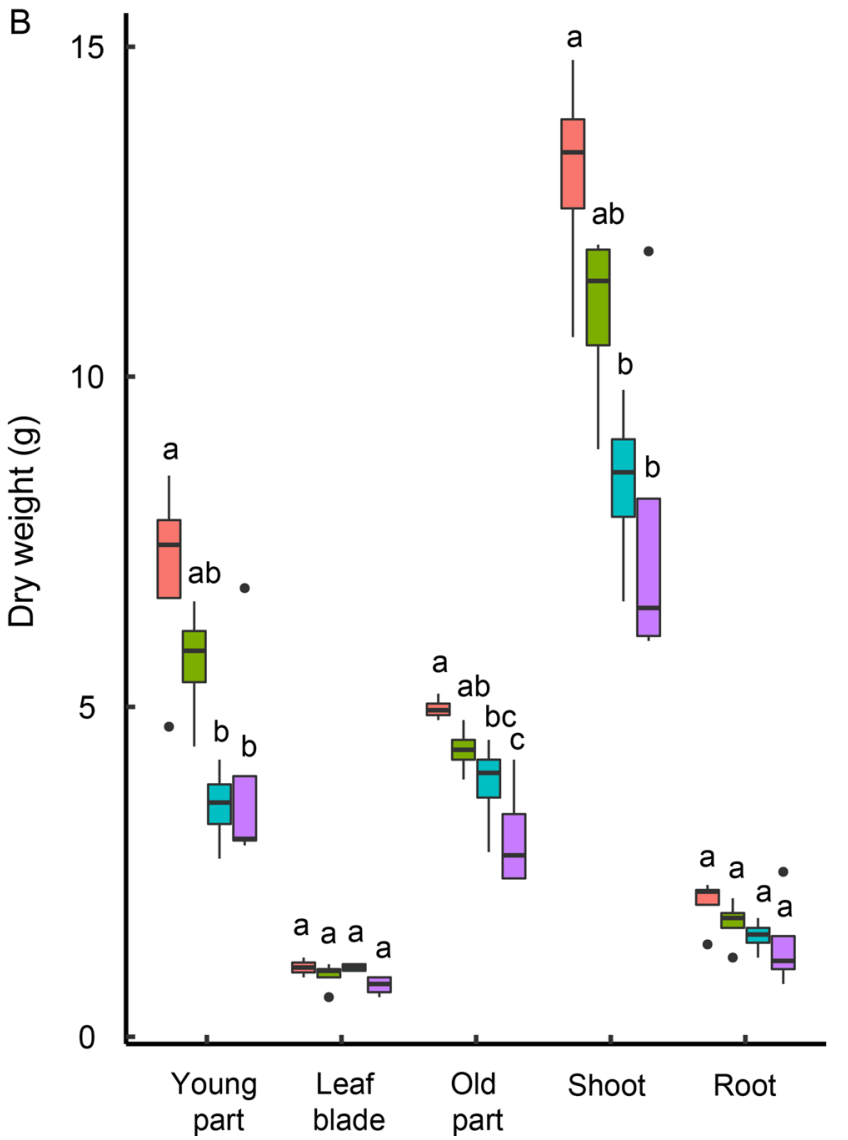

ferent treatments $(n=4)$. Shoot represents all above-ground parts, i.e., a mathematic sum of the young part, fully developed leaf blade, and old part

\section{Estimated chlorophyll concentration, stomatal conductance, transpiration rate, and net photosynthetic rate in the fully developed leaf blade}

The chlorophyll concentration per unit of leaf area, as estimated by SPAD readings, gradually increased from 6 to 13 days after treatment (DAT) and afterwards reached a constant level at 18 and 19 DAT in control, moderate $\mathrm{Cl}^{-}$and high $\mathrm{Cl}^{-}$(Fig. 4a). Under the condition of osmotic stress, the chlorophyll concentration always kept constant among the whole period and was also significantly lower than other conditions at 13,18, and 19 DAT (Fig. 4a). Notably, there were no differences in SPAD readings between different $\mathrm{Cl}^{-}$applications regardless of how long the plants were treated (Fig. 4a).

High $\mathrm{Cl}^{-}$stress and osmotic stress significantly decreased $g_{s}$ and $\mathrm{E}$ (Fig. $4 \mathrm{~b}$ and c) but did not reduce $\mathrm{A}_{\mathrm{N}}$ 
Treatment 它 Control $\left(2 \mathrm{mM} \mathrm{CaCl}_{2}\right)$ 官 Moderate $\mathrm{Cl}^{-}\left(10 \mathrm{mM} \mathrm{CaCl}_{2}\right)$ 官 $\mathrm{High} \mathrm{Cl}^{-}\left(60 \mathrm{mM} \mathrm{CaCl}_{2}\right)$ 官 Osmotic stress $(\mathrm{PEG}+2 \mathrm{mM} \mathrm{CaCl})$

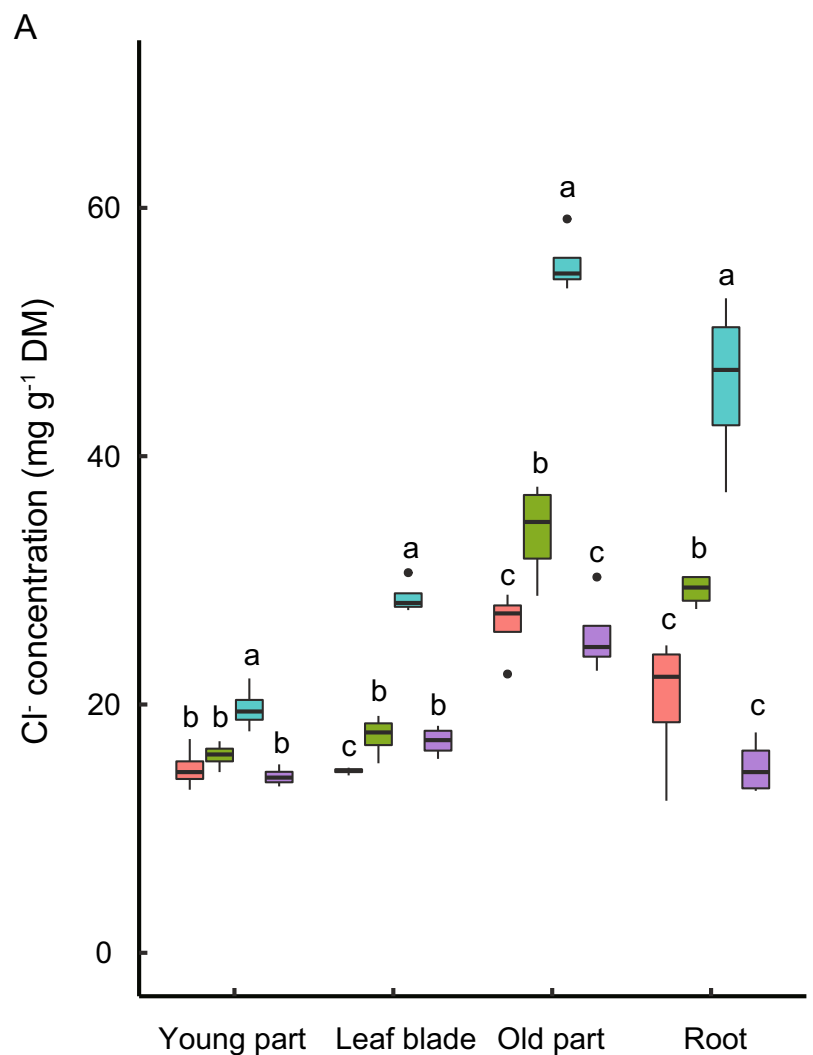

Fig. 3 Chloride concentration of all fractions, nitrate reductase activity and nitrate concentration in the fully developed leaf blade. $\mathrm{C} \mathrm{Cl}^{-}$ concentration of all fractions, b nitrate reductase activity (NRA) in the fully developed leaf blade, $\mathbf{c ~ N O}-$ concentration in the fully

(Fig. 4d) and intercellular $\mathrm{CO}_{2}$ concentration (Fig. S2) in comparison with the control.

\section{Principal component analysis}

In principal component analysis (PCA) (Fig. 5), the high $\mathrm{Cl}^{-}$treatment and osmotic treatment were primarily found on the right side of the first and fourth quadrants of the middle axis, respectively, whereas the control and moderate $\mathrm{Cl}^{-}$treatment generally lay together in the second and third quadrants. All 15 physiological variables in response to the various $\mathrm{Cl}^{-}$applications were comprehensively analyzed, and a large part of the variability could be explained by the first two principal components (PC1 44.6\% and PC2 18.4\%). In detail, the osmolality (data shown in Fig. S3) of all fractions was allocated in the high $\mathrm{Cl}^{-}$cluster. The fresh and dry biomass of shoots and roots and the SPAD were in the upper left quadrant. Moreover, the gas exchange variables $\left(\mathrm{g}_{\mathrm{s}}, \mathrm{E}\right.$ and $\left.\mathrm{A}_{\mathrm{N}}\right), \mathrm{NO}_{3}^{-}$metabolism parameters (NRA and $\mathrm{NO}_{3}^{-}$
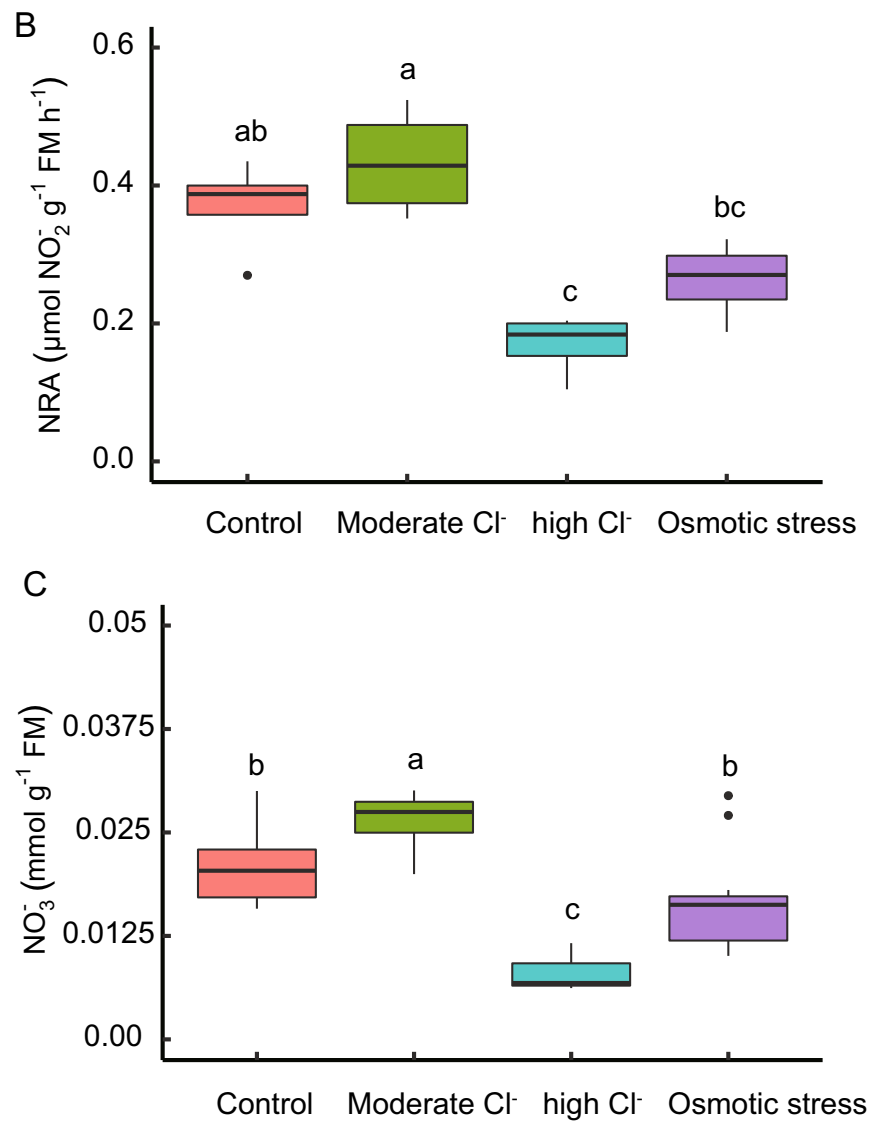

developed leaf blade. Small letters represent significant differences $(\mathrm{P}<0.05$, LSD test) in one tissue group under the different treatments $\left(\mathrm{Cl}^{-}\right.$concentration and $\mathrm{NRA}, \mathrm{n}=4 ; \mathrm{NO}_{3}^{-}$concentration, $\left.\mathrm{n}=12\right)$

concentration), and ion leakage (data shown in Fig. S4) clustered in the lower left quadrant.

\section{Discussion}

\section{Effects of $\mathrm{Cl}^{-}$application and osmotic stress on biomass}

The present experiments indicate that $\mathrm{Cl}^{-}$has no direct ionic toxicity on shoot biomass, in which the osmotic component induced by excessive $\mathrm{Cl}^{-}$is responsible for the biomass reduction. This is verified by the biomass data of PEG-induced osmotic stress (Fig. 2), in which a lower osmotic pressure (only $57 \%$ of that produced by high $\mathrm{Cl}^{-}$) results in a shoot biomass reduction as similar as high $\mathrm{Cl}^{-}$stress for 19 days after treatment. Besides, the close negative correlation between the biomass of whole plants and PEG-induced osmotic stress indicated by the PCA pattern (arrows in opposite directions, 
Treatment 官 Control $\left(2 \mathrm{mM} \mathrm{CaCl}_{2}\right)$ 官 Moderate $\mathrm{Cl}^{-}\left(10 \mathrm{mM} \mathrm{CaCl}_{2}\right)$ 官 High Cl $\left(60 \mathrm{mM} \mathrm{CaCl}_{2}\right)$ 官 Osmotic stress $\left.(\mathrm{PEG}+2 \mathrm{mM} \mathrm{CaCl})_{2}\right)$

A
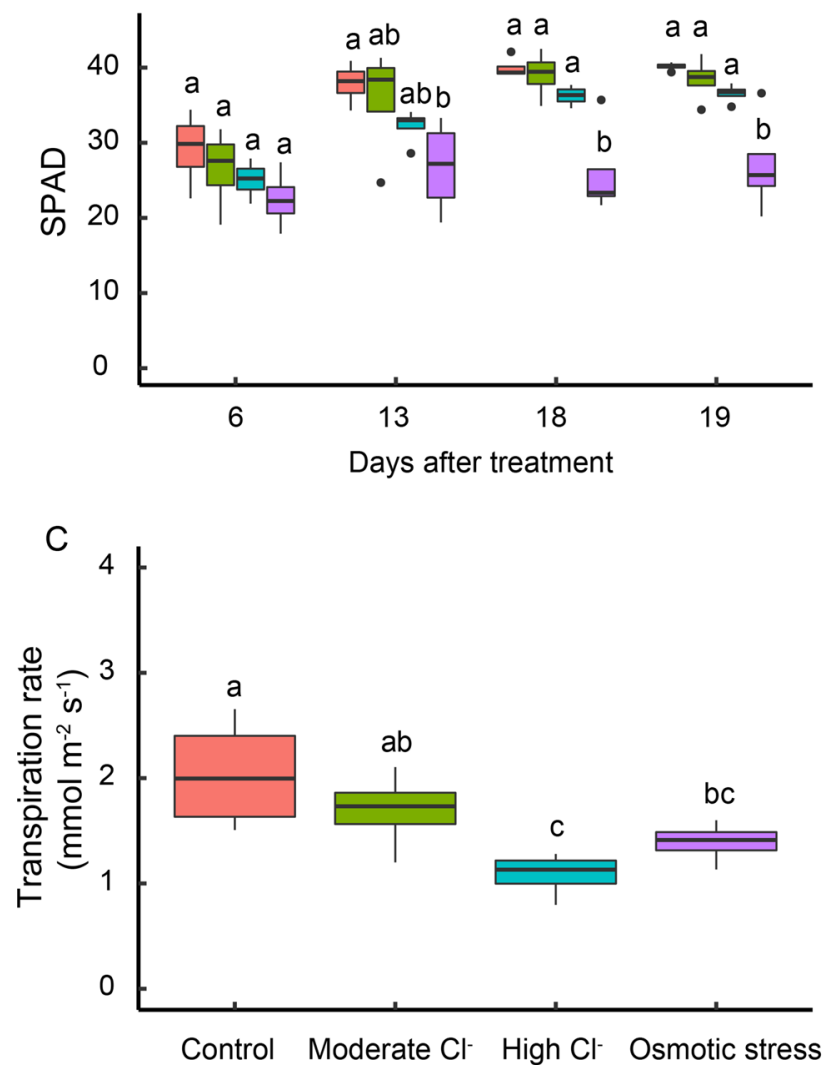

Fig. 4 Estimated chlorophyll concentration, stomatal conductance, transpiration rate, and net photosynthetic rate in the fully developed leaf blade. a Estimated chlorophyll concentration as indicated by SPAD, b stomatal conductance, $\mathbf{c}$ transpiration rate and $\mathbf{d}$ net photosynthetic rate. In subfigure $A$, small letters represent significant differences $(\mathrm{P}<0.05$, LSD test $)$ under the different treatments at each
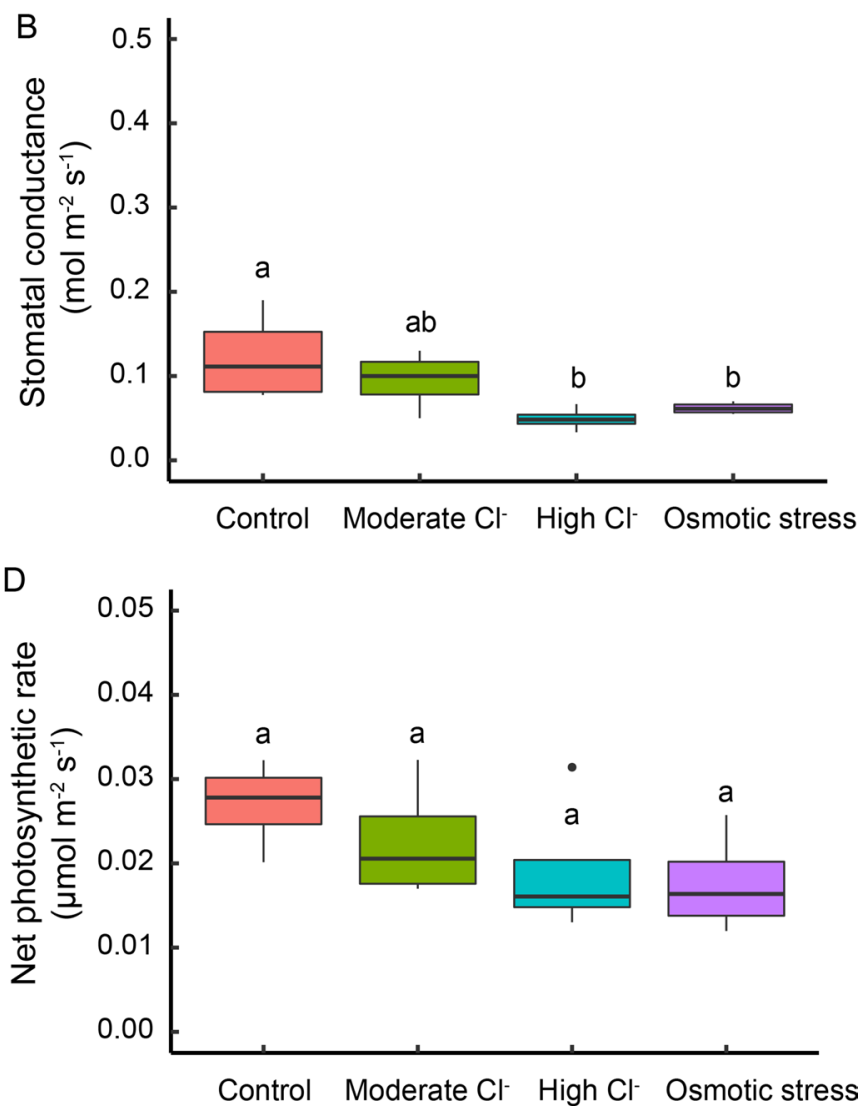

time point after treatment $(n=4)$. In subfigures $B, C$ and $D$, average values of the 6th, 13th, 18th, and 19th days after the treatment are regarded as raw data for whisker-box plotting. Small letters represent significant differences $(\mathrm{P}<0.05$, LSD test) in stomatal conductance, transpiration rate, and net photosynthetic rate under the different treatments $(\mathrm{n}=4)$
Fig. 5) suggest that osmotic stress plays a more vital role in the reduction of plant biomass. Furthermore, the similar visual appearance of small necrotic symptoms on the older leaves (Fig. S5) is observed under both high $\mathrm{Cl}^{-}$stress and the PEGinduced osmotic treatment. The necrotic symptoms of old leaves are believed to be caused by osmotic stress, which was also found in $\mathrm{NaCl}$ stressed maize seedlings (Cramer et al. 1994; De Costa et al. 2007). The comparisons of shoot biomass (Fig. 2) and necrotic symptoms (Fig. S5) between PEGinduced osmotic treatment and control further proves that the osmotic-stress-induced growth inhibition or leaf necrosis in maize is not specific to $\mathrm{Cl}^{-}$.

\section{Context of $\mathrm{Cl}^{-}$and estimated chlorophyll concentration, stomatal conductance, transpiration rate, and photosynthesis rate}

Osmotic stress is a serious threat to chlorophyll concentration indicated by SPAD; indeed, it caused a decrease of $32.6 \%$ under PEG-induced osmotic treatment (Fig. 4a) and a clear negative correlation between SPAD and osmotic stress cluster by PCA plots (Fig. 5). This is in agreement with the observation that water stress can reduce the chlorophyll concentration up to $40 \%$ without adversely affecting photosynthesis at mid-day in maize (Sanchez et al. 1983). 


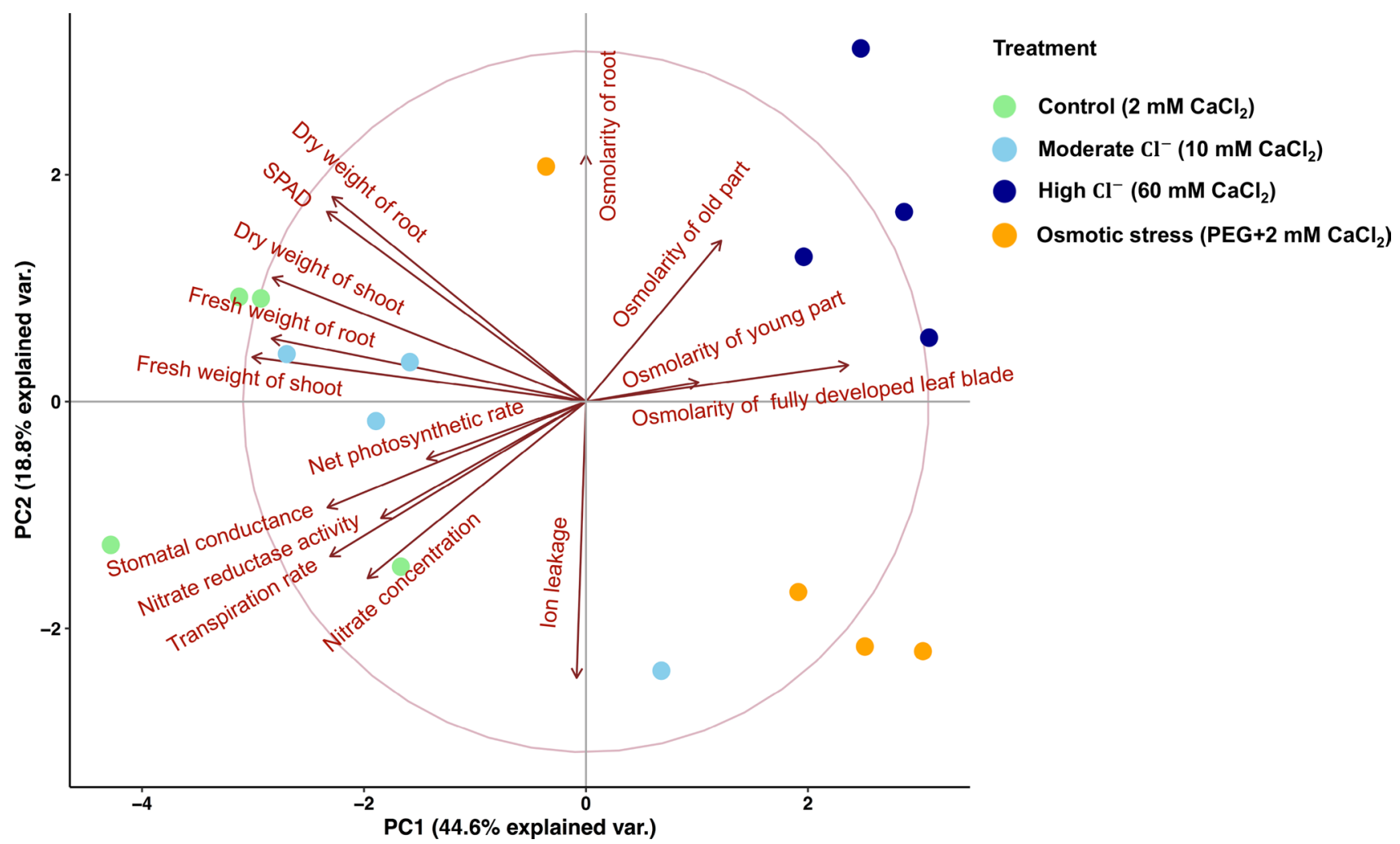

Fig. 5 Principal component analysis of 15 variables in maize responding to $\mathrm{Cl}^{-}$application or osmotic treatment

In parallel, the uncompromised photosynthesis was also observed in the present experiment (Fig. 4d). Interestingly, chlorophyll reduction did not appear in high $\mathrm{Cl}^{-}$application with higher osmotic stress (Fig. 4a). It could be resulted from the osmotic adjustment of $\mathrm{Cl}^{-}$, in which the leaf blade had a considerably higher $\mathrm{Cl}^{-}$concentration under $60 \mathrm{mM}$ $\mathrm{CaCl}_{2}$ than PEG-induced osmotic stress (Fig. 3a). In addition, there was no significant difference in SPAD readings between varied $\mathrm{Cl}^{-}$doses at the whole treatment period. Therefore, reductions of chlorophyll concentration in maize result from osmotic stress rather than from $\mathrm{Cl}^{-}$ionic toxicity.

The reduced stomatal conductance $\left(\mathrm{g}_{\mathrm{s}}\right)$ (Fig. $4 \mathrm{~b}$ ) decreased $\mathrm{E}$ (Fig. 4c) but did not disturb $\mathrm{A}_{\mathrm{N}}$ (Fig. 4d) under high $\mathrm{Cl}^{-}$stress and PEG-induced osmotic stress. One reason might be that the stomatal regulation predominantly minimizes water loss while only marginally inhibiting $\mathrm{CO}_{2}$ assimilation (Farquhar and Sharkey 1982). This can be evidenced by the data (Fig. $4 \mathrm{~b}$ and Fig. S2), which showed that reduced $\mathrm{g}_{\mathrm{s}}$ did not influence intercellular $\mathrm{CO}_{2}$ concentration by high $\mathrm{Cl}^{-}$stress and osmotic stress.

\section{Inhibitory effects of $\mathrm{Cl}^{-}$stress on NRA in maize}

The negative correlation of $\mathrm{NO}_{3}^{-}$metabolism variables $\left(\mathrm{NO}_{3}^{-}\right.$ concentration and NRA) and gas exchange parameters $\left(\mathrm{g}_{\mathrm{s}}, \mathrm{E}\right.$, and $\mathrm{A}_{\mathrm{N}}$ ) with $\mathrm{Cl}^{-}$stress was stronger than that with osmotic stress, as shown by the PCA results (Fig. 5). Therefore, the correlation differences indicate that the mechanism of $\mathrm{NO}_{3}^{-}$ metabolic interference between osmotic stress and $\mathrm{Cl}^{-}$stress is different (as shown by proposed mechanisms in Fig. 6).

Under PEG-induced osmotic stress (plus $2 \mathrm{mM} \mathrm{CaCl}{ }_{2}$ ), the osmotic imbalance caused more $\mathrm{Cl}^{-}$to enter into the leaf cells (Figs. 3a and 6a) probably because of $\mathrm{Cl}^{-}$as a 'cheap' osmoticum (Wege et al. 2017). Apart from this, $\mathrm{Cl}^{-}$is also thought to liberate (by means of substitution) other osmotica such as proline, sucrose, malate, $\mathrm{K}^{+}$, and $\mathrm{NO}_{3}^{-}$for use in other functions (Flowers 1988). The osmotic adjustment of $\mathrm{Cl}^{-}$is beneficial to help plants adapt the osmotic stress. Although PEG-induced osmotic stress significantly reduced $\mathrm{E}$ (Figs. $4 \mathrm{c}$ and $6 \mathrm{a}$ ), the decreased mass flow did not induce a reduction of $\mathrm{NO}_{3}^{-}$concentration in the fully leaf blade as well as NRA (Figs. 3b, c and 6a).

The addition of excess $\mathrm{Cl}^{-}$has considerably reduced $\mathrm{NO}_{3}^{-}$ concentration in the fully developed leaf blade, and thereby decreasing NRA (Figs. 3 and 6b). It arises a question how the overdose of external $\mathrm{Cl}^{-}$results in a considerable reduction of $\mathrm{NO}_{3}^{-}$concentration in the distant leaves via the competitive uptake with $\mathrm{NO}_{3}^{-}$or the reduced $\mathrm{NO}_{3}^{-}$translocation by decreased mass flow or both. The antagonistic uptake between $\mathrm{Cl}^{-}$and $\mathrm{NO}_{3}^{-}$has been well documented, because these two monovalent anions share a $\mathrm{NO}_{3}^{-}$transporter $Z m$ NPF6.4, which is a root-located transmembrane protein 
A

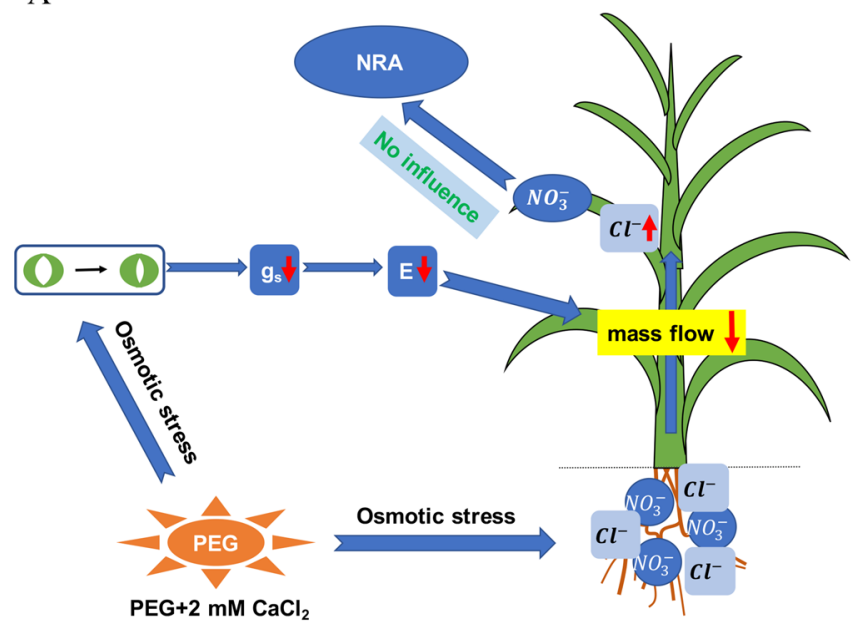

Fig. 6 Proposed mechanisms of NRA interference by $\mathrm{Cl}^{-}$stress or osmotic stress in maize. a PEG-induced osmotic stress $+2 \mathrm{mM}$ $\mathrm{CaCl}_{2}, \mathbf{b ~ C l}{ }^{-}$stress $\left(60 \mathrm{mM} \mathrm{CaCl}{ }_{2}\right)$. Abbreviations are as following: $\mathrm{Cl}^{-}$chloride, $\mathrm{NO}_{3}^{-}$nitrate, $\mathrm{NRA}$ nitrate reductase activity, $\mathrm{g}_{s}$ stomatal

(Wen et al. 2017). Wen et al. (2017) found that an increase of external $\mathrm{Cl}^{-}$concentration from 0 to $10 \mathrm{mM}$ could facilitate $\mathrm{Cl}^{-}$uptake of $Z m N P F 6.4$. It explains the competition to $\mathrm{NO}_{3}^{-}$ uptake. Besides, the effect of reduced $\mathrm{NO}_{3}^{-}$translocation via mass flow could be excluded or at least very tiny, although the data of $\mathrm{NO}_{3}^{-}$xylem translocation was not measured at the present work. It can be well evidenced by transpiration rate data (Fig. 4c), because PEG-induced osmotic stress and $60 \mathrm{mM} \mathrm{CaCl}_{2}$ stress caused the similar reduction of $\mathrm{E}$, but the decreased mass flow indicated by $\mathrm{E}$ did not show a negative effect on leaf $\mathrm{NO}_{3}^{-}$concentration under PEG-induced osmotic stress (Figs. 3c and 4c). Therefore, it is reasonably believed that the competitive uptake between $\mathrm{Cl}^{-}$and $\mathrm{NO}_{3}^{-}$ is the primary culprit to decrease leaf $\mathrm{NO}_{3}^{-}$concentration, and the lack of substrate $\left(\mathrm{NO}_{3}^{-}\right)$restricts the NRA, since NR is a typical substrate-induced enzyme (Flores et al. 2000).

To compare both stresses, NR activity was significantly decreased by high $\mathrm{Cl}^{-}$stress due to the antagonism with $\mathrm{NO}_{3}^{-}$, but no influence was observed in osmotic stress (Fig. 6). However, the difference in NR activity did not affect biomass production, since both stresses always had identical biomass (Fig. 2). Therefore, this discrepancy is reasonably supposed to be a beneficial aspect of $\mathrm{Cl}^{-}$, because a higher amount of $\mathrm{Cl}^{-}$was accumulated in the developed leaf blade under high $\mathrm{Cl}^{-}$, nearly 1.7 times as high as that of osmotic stress (Fig. 3a). Geilfus (2018a) reported that $\mathrm{Cl}^{-}$could promote cell growth by regulating osmotic potential and turgor pressure.

In order to overcome this $\mathrm{Cl}^{-} / \mathrm{NO}_{3}^{-}$uptake competition under saline conditions, genetic modifications have been conducted in crops, e.g., the overexpression of chloride channels (GmCLC1, GsCLC-c2) in the hairy roots of
$\mathrm{B}$

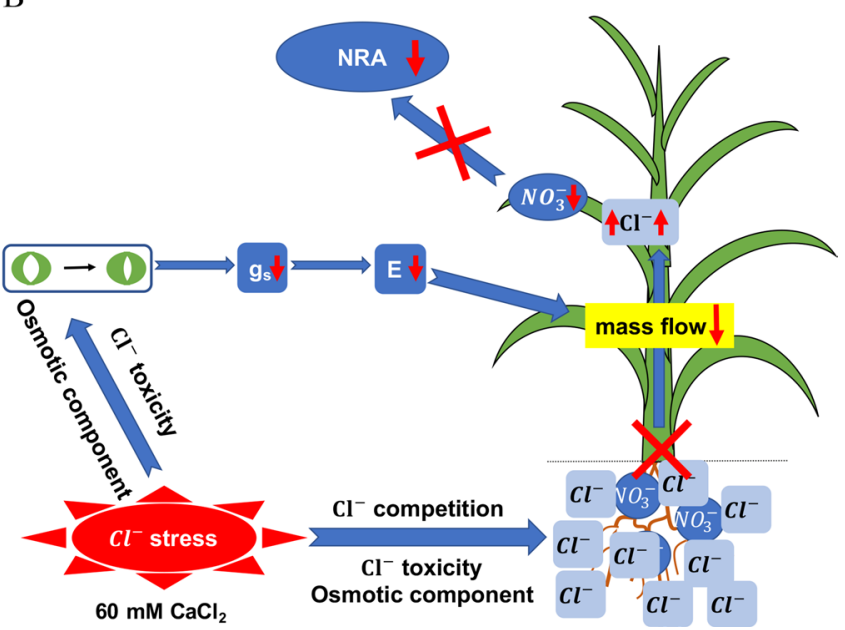

conductance, $E$ transpiration rate, " $"$, an increase of the corresponding parameter, " $\downarrow$ ", a decrease of the corresponding parameter, " $\mathrm{X}$ " the breakdown of the corresponding biological process

soybean which has been found to enhance salt tolerance. The over-expressed transport protein is highly correlated with the significant decrease of $\mathrm{Cl}^{-}$concentration in shoots and then indirectly maintains a high $\mathrm{NO}_{3}^{-}$accumulation in plant tissues. As a result, the ratio of $\mathrm{Cl}^{-} / \mathrm{NO}_{3}^{-}$remains constant in the stems and leaves of soybean (Wei et al. 2016, 2019). Nevertheless, whether this sole remedy is really sufficient to guarantee the metabolic function of NR in leaves under saline conditions remains unclear, because a preliminary question that if mass flow directly influence $\mathrm{NO}_{3}^{-}$ xylem translocation under osmotic stress should be firstly answered. If this effect depends on osmotic intensity or crop species, then the genetically modified strategy would not be working efficiently.

\section{Conclusions}

Maize is more sensitive to osmotic stress rather than $\mathrm{Cl}^{-}$ion toxicity. $\mathrm{Cl}^{-}$has beneficial effects on mitigating the osmotic stress via osmotic adjustment. Osmotic stress did not interfere NRA, since leaf $\mathrm{NO}_{3}^{-}$concentration was not reduced. A link between $\mathrm{Cl}^{-}$stress and NRA has been established in $\mathrm{Cl}^{-}$-stressed plants: the decreased NRA might be primarily caused by the antagonistic uptake of $\mathrm{Cl}^{-}$and $\mathrm{NO}_{3}^{-}$, finally resulting in the scarcity of metabolically available $\mathrm{NO}_{3}^{-}$in leaf tissues.

Acknowledgements This work was financially supported by the China Scholarship Council (Grant Number 201606300005) and Deutsche Forschungsgemeinschaft (ZO/08); project number 320167376. We cordially acknowledge the kind technical assistance of Dr. Nikolaus Merkt and Mrs Christiane Beierle in the greenhouse and laboratory, 
respectively. We also would like to show many thanks to the contribution of Mrs. Lilit Manukyan in the final language check.

Author contributions $\mathrm{C}-\mathrm{MG}$ and $\mathrm{CZ}$ designed the concept and the experiments. $\mathrm{XZ}$ and LE conducted the experiments in the greenhouse and laboratory. BF supervised the cultivation of plants and took part in the data interpretation. $\mathrm{XZ}$ was responsible for data analysis, figures plotting, results discussion and manuscript drafting.

Funding Open Access funding enabled and organized by Projekt DEAL.

\section{Compliance with ethical standards}

Conflict of interest The authors declare that they have no conflict of interest.

Open Access This article is licensed under a Creative Commons Attribution 4.0 International License, which permits use, sharing, adaptation, distribution and reproduction in any medium or format, as long as you give appropriate credit to the original author(s) and the source, provide a link to the Creative Commons licence, and indicate if changes were made. The images or other third party material in this article are included in the article's Creative Commons licence, unless indicated otherwise in a credit line to the material. If material is not included in the article's Creative Commons licence and your intended use is not permitted by statutory regulation or exceeds the permitted use, you will need to obtain permission directly from the copyright holder. To view a copy of this licence, visit http://creativecommons.org/licenses/by/4.0/.

\section{References}

Abdelaal KAA, Mazrou YSA, Hafez YM (2020) Silicon foliar application mitigates salt stress in sweet pepper plants by enhancing water status, photosynthesis, antioxidant enzyme activity and fruit yield. Plants 9(6):733

Botella MA, Cruz C, Martins-Louçao MA, Cerdá A (1993) Nitrate reductase activity in wheat seedlings as affected by $\mathrm{NO}_{3}{ }^{-} / \mathrm{NH}_{4}{ }^{+}$ ratio and salinity. J Plant Physiol 142:531-536

Brumos J, Talon M, Bouhlal R, Colmenero-flores JM (2010) Cl-homeostasis in includer and excluder citrus rootstocks: transport mechanisms and identification of candidate genes. Plant Cell Environ 33:2012-2027

Chamizo-Ampudia A, Sanz-Luque E, Llamas A, Galvan A, Fernandez E (2017) Nitrate reductase regulates plant nitric oxide homeostasis. Trends Plant Sci 22(2):163-174

Cramer G, Alberico G, Schmidt C (1994) Salt tolerance is not associated with the sodium accumulation of two maize hybrids. Funct Plant Biol 21:675-692

Crawford NM, Glass AD (1998) Molecular and physiological aspects of nitrate uptake in plants. Trends Plant Sci 3:389-395

De Costa W, Zörb C, Hartung W, Schubert S (2007) Salt resistance is determined by osmotic adjustment and abscisic acid in newly developed maize hybrids in the first phase of salt stress. Physiol Plant 131:311-321

De Mendiburu F (2017) Statistical procedures for agricultural research. $\mathrm{R}$ package version 1.2-8. https://CRAN.R-project.org/packa ge $=$ agricolae

Ebert G, Eberle J, Ali-Dinar H, Lüdders P (2002) Ameliorating effects of $\mathrm{Ca}\left(\mathrm{NO}_{3}\right)_{2}$ on growth, mineral uptake and photosynthesis of $\mathrm{NaCl}$-stressed guava seedlings (Psidium guajava L.). Sci Hortic 93:125-135
Farooq M, Hussain M, Wakeel A, Siddique KH (2015) Salt stress in maize: effects, resistance mechanisms, and management. A review. Agron Sustain Dev 35:461-481

Farquhar GD, Sharkey TD (1982) Stomatal conductance and photosynthesis. Annu Rev Plant Physiol 33:317-345

Flores P, Botella M, Martinez V, Cerdá A (2000) Ionic and osmotic effects on nitrate reductase activity in tomato seedlings. J Plant Physiol 156:552-557

Flowers T (1988) Chloride as a nutrient and as an osmoticum. Adv Plant Nutr (USA) 3:55-78

Franco-Navarro JD, Rosales MA, Cubero-Font P, Calvo P, Álvarez R, Diaz-Espejo A, Colmenero-Flores JM (2019) Chloride as macronutrient increases water use efficiency by anatomically-driven reduced stomatal conductance and increased mesophyll diffusion to $\mathrm{CO}_{2}$. Plant J 99(5):815-831

Gaj R, Budka A, Górski D, Borowiak K, Wolna-Maruwka A, Bak K (2018) Magnesium and calcium distribution in maize under differentiated doses of mineral fertilization with phosphorus and potassium. J Elementol 23:137-150

Geilfus CM (2018a) Chloride: from nutrient to toxicant. Plant Cell Physiol 59:877-886

Geilfus CM (2018b) Review on the significance of chlorine for crop yield and quality. Plant Sci 270:114-122

Hageman R, Hucklesby D (1971) Nitrate reductase from higher plants. In: Pietro AS (ed) Methods in enzymology, vol 23. Elsevier, Amsterdam, pp 491-503

He YN, Peng JS, Cai Y, Liu DF, Guan Y, Yi HY, Gong JM (2017) Tonoplast-localized nitrate uptake transporters involved in vacuolar nitrate efflux and reallocation in Arabidopsis. Sci Rep 7:6417

Hütsch BW, He W, Schubert S (2016) Nitrogen nutritional status of young maize plants (Zea mays L.) is not limited by $\mathrm{NaCl}$ stress. J Plant Nutr Soil Sci 179:775-783

Johnston AM, Dowbenko R (2004) Essential elements in corn. In: Bittman S, Kowalenko CG (eds) Advanced silage corn management. Pacific Corn Association, Agassiz, p 24-27. https://farmwest.com/ resources/books/advanced-silage-corn-management-2004/

Kawakami K, Umena Y, Kamiya N, Shen JR (2009) Location of chloride and its possible functions in oxygen-evolving photosystem II revealed by X-ray crystallography. Proc Natl Acad Sci USA 106:8567-8572

Khan M, Silberbush M, Lips S (1995) Physiological studies on salinity and nitrogen interaction in alfalfa plants: III. Nitrate reductase activity. J Plant Nutr 18:2495-2500

Larsson M, Larsson CM, Whitford P, Clarkson D (1989) Influence of osmotic stress on nitrate reductase activity in wheat (Triticum aestivum L.) and the role of abscisic acid. J Exp Bot 40:1265-1271

Lu JL, Ertl JR, Chen CM (1992) Transcriptional regulation of nitrate reductase mRNA levels by cytokinin-abscisic acid interactions in etiolated barley leaves. Plant Physiol 98:1255-1260

Mengel K, Robin P, Salsac L (1983) Nitrate reductase activity in shoots and roots of maize seedlings as affected by the form of nitrogen nutrition and the $\mathrm{pH}$ of the nutrient solution. Plant Physiol 71:618-622

Munjal N, Sawhney SK, Sawhney V (1997) Activation of nitrate reductase in extracts of water stressed wheat. Phytochemistry 45:659-665

Munns R, Tester M (2008) Mechanisms of salinity tolerance. Annu Rev Plant Biol 59:651-681

Naeem M, Iqbal M, Shakeel A, Ul-Allah S, Hussain M, Rehman A, Zafar ZU, Athar H, Ashraf M (2020) Genetic basis of ion exclusion in salinity stressed wheat: implications in improving crop yield. Plant Growth Regul 92:479

Richter JA, Erban A, Kopka J, Zörb C (2015) Metabolic contribution to salt stress in two maize hybrids with contrasting resistance. Plant Sci 233:107-115 
Rognes SE (1980) Anion regulation of lupin asparagine synthetase: chloride activation of the glutamine-utilizing reactions. Phytochemistry 19:2287-2293

Rosales MA, Franco-Navarro JD, Peinado-Torrubia P, Díaz-Rueda P, Álvarez R, Colmenero-Flores JM (2020) Chloride improves nitrate utilization and NUE in plants. Front Plant Sci 11:442

Sanchez R, Hall A, Trapani N, De Hunau RC (1983) Effects of water stress on the chlorophyll content, nitrogen level and photosynthesis of leaves of two maize genotypes. Photosynthesis Res 4:35-47

Venables W, Ripley B (2002) Modern applied statistics with S. Springer, New York

Vu VQ (2016) Ggbiplot: A ggplot2 based biplot. R package version 0.55. 2011.

Wege S, Gilliham M, Henderson SW (2017) Chloride: not simply a 'cheap osmoticum', but a beneficial plant macronutrient. J Exp Bot 68:3057-3069

Wei P, Wang L, Liu A, Yu B, Lam HM (2016) GmCLC1 confers enhanced salt tolerance through regulating chloride accumulation in soybean. Front Plant Sci 7:1082

Wei P, Che B, Shen L, Cui Y, Wu S, Cheng C, Liu F, Li MW, Yu B, Lam HM (2019) Identification and functional characterization of the chloride channel gene, GsCLC-c2 from wild soybean. BMC Plant Biol 19:121

Wen Z, Tyerman SD, Dechorgnat J, Ovchinnikova E, Dhugga KS, Kaiser BN (2017) Maize NPF6 proteins are homologs of Arabidopsis
CHL1 that are selective for both nitrate and chloride. Plant Cell 29(10):2581-2596

Xu N, Wang R, Zhao L, Zhang C, Li Z, Lei Z, Liu F, Guan P, Chu Z, Crowford NM, Wang Y (2016) The Arabidopsis NRG2 protein mediates nitrate signaling and interacts with and regulates key nitrate regulators. Plant Cell 28:485-504

Zhang H, Zhao FG, Tang RJ, Yu Y, Song J, Wang Y, Li L, Luan S (2017) Two tonoplast MATE proteins function as turgor-regulating chloride channels in Arabidopsis. Proc Natl Acad Sci USA 114:E2036-E2045

Zhang X, Zörb C, Kränzlein M, Franzisky BL, Kaiser H, Geilfus CM (2019) The early stress response of maize (Zea mays L.) to chloride salinity. J Agron Crop Sci 205:586-597

Zörb C, Mühling KH, Kutschera U, Geilfus CM (2015) Salinity stiffens the epidermal cell walls of salt-stressed maize leaves: is the epidermis growth-restricting? PLoS ONE 10:e0118406

Zörb C, Geilfus CM, Dietz KJ (2019) Salinity and crop yield. Plant Biol 21:31-38

Publisher's Note Springer Nature remains neutral with regard to jurisdictional claims in published maps and institutional affiliations. 